\title{
Respon Morfologi Kedelai (Glycine max L.) Varietas Anjasmoro Hasil Iradiasi Sinar Gamma pada Cekaman Genangan
}

\author{
Elena Rosalia Firsta dan Triono Bagus Saputro \\ Departemen Biologi, Fakultas Ilmu Alam, Institut Teknologi Sepuluh Nopember (ITS) \\ e-mail: trionobsaputro@bio.its.ac.id
}

\begin{abstract}
Abstrak-Kedelai (Glycine max L.) merupakan komoditi pangan utama, mengandung kalori, protein, lemak, karbohidrat, air, serta beberapa mineral. Varietas Anjasmoro merupakan varietas kedelai yang memiliki resistensi terhadap hama penyakit, memiliki produksi biji polong dan tinggi tanaman yang baik. Penelitian mengenai tanaman pangan khususnya kedelai pada genangan masih kurang sehingga informasi mengenai kultivar toleran genangan masih terbatas. Salah satu cara yang dapat dilakukan untuk meningkatkan ketahanan varietas kedelai adalah melakukan induksi mutasi iradiasi sinar gamma. Dosis iradiasi sinar gamma yang diberikan pada benih kedelai adalah 0 Gy, 25 Gy, 50 Gy, 75 Gy dan 100 Gy. Cekaman genangan yang diberikan 0\%, 100\%, $150 \%, 200 \%$ dan $250 \%$. Klon varietas Anjasmoro hasil iradiasi sinar gamma pada viabilitas dan vigoritas dianalisis dengan Anova one way, faktor iradiasi dan genagan pada parameter morfologi dianalisis dengan Anova two way, dilanjutkan dengan uji DMRT pada taraf 95\%. Iradiasi sinar gamma pada benih tanaman kedelai varietas Anjasmoro memberikan pengaruh yang tidak signifikan. Dosis iradiasi tinggi (high irradiation dose) 100 Gy pada benih kedelai menurunkan viabilitas dan vigoritas. Dosis iradiasi 100 Gy dan genangan $250 \%$ menurunkan morfologi tanaman. Parameter viabilitas vigoritas dan morfologi terbaik terdapat pada dosis iradiasi sinar gamma dengan dosis rendah (low irradiation dose) dimana daya berkecambah terbaik terdapat pada iradiasi 25 Gy dan 50 Gy, laju perkecambahan terbaik terdapat pada perlakuan kontrol, sedangkan keserempakan tumbuh terbaik terdapat pada perlakuan kontrol dan iradiasi 25 Gy. Tinggi tanaman terbaik pada iridiasi 25 Gy pada genangan kontrol dan Luas daun terbaik berada pada iradiasi 50 Gy genangan kontrol.
\end{abstract}

Kata Kunci-Cekaman Genangan, Iradiasi Sinar Gamma, Kedelai Varietas Anjasmoro, Morfologi, Perkecambahan.

\section{PENDAHULUAN}

$\mathrm{K}$ EDELAI (Glycine max L.) merupakan komoditi pangan utama setelah padi dan jagung. Setiap 100 gram biji kedelai rata-rata mengandung 330 kalori, $35 \%$ protein, $18 \%$ lemak, 35\% karbohidrat, $10 \%$ air, serta beberapa mineral seperti $\mathrm{Ca}, \mathrm{Fe}$, vitamin A, dan vitamin B1 [1]. Biji kedelai, selain sebagai bahan makanan juga merupakan bahan dasar untuk industri pangan, sedangkan batang dan daunnya juga dapat bermanfaat sebagai pakan ternak, pupuk hijau dan akar-akar yang tertinggal di dalam tanah maupun daun yang rontok dapat memperbaiki kesuburan tanah [2].

Tingginya manfaat kedelai menyebabkan kebutuhan kedelai dari tahun ke tahun semakin meningkat. Peningkatan permintaan tersebut tidak diikuti dengan peningkatan produksi. Diperkirakan tiap tahun rata-rata kebutuhan kedelai mencapai 2,2 juta ton/tahun dan diprediksi akan meningkat setiap tahunnya. Namun, hingga tahun 2016 produksi kedelai diperkirakan berada pada kisaran 800-900 ribu ton [3].

Defisit produksi kedelai tersebut dapat disebabkan oleh kondisi lingkungan. Salah satu faktor utama penentu kondisi lingkungan yaitu tinginya curah hujan di Indonesia. Periode musim hujan yang lama berpotensi menyebabkan kondisi genangan. Terjadinya stres genangan air didefinisikan ketika pori-pori tanah jenuh air yang menjadi over kapasitas tanah setidaknya $20 \%$ [4].

Stres genangan air (waterlogging) dapat menyebabkan rendahnya pasokan $\mathrm{O}_{2}$ pada bagian perakaran, penuaan dini sehingga daun klorosis, nekrosis, dan gugur serta pertumbuhan tanaman terhambat yang pada akhirnya menurunkan hasil (produktivitas). Besarnya penurunan hasil ini juga tergantung pada varietas kedelai yang ditanam, fase pertumbuhan tanaman, lamanya tergenang, tekstur tanah, adanya penyakit [5][6], dan [7].

Varietas Anjasmoro merupakan varietas kedelai unggulan. Kedelai ungggulan adalah salah satu varietas kedelai yang sudah teruji kemampuan dan prospek maupun potensinya dalam berbagai kebutuhan pertanian [8]. Anjasmoro memiliki resistensi terhadap hama penyakit, memiliki produksi biji polong dan tinggi tanaman yang baik pada sentra produksi, serta varietas ini mampu melebihi produktivitas rerata nasional, yang artinya varietas Anjasmoro dominan bertahan sampai matang ketimbang varietas lainnya [9].

Penelitian mengenai tanaman pangan khususnya kedelai pada genangan masih kurang sehingga informasi mengenai kultivar toleran genangan masih terbatas. Rendahnya keragaman atau tidak adanya sumber ketahanan terhadap genangan pada tanaman kedelai menuntut adanya induksi varietas baru tahan kondisi genangan. Varietas yang menunjukkan ketahanan terhadap cekaman genangan dapat digunakan sebagai sumber plasma nutfah yang digunakan untuk persilangan tanaman kedelai. Varietas baru yang tahan genangan dapat digunakan untuk meningkatkan produksi tanaman kedelai nasional [7].

Penggabungan teknik iradiasi atau induksi mutasi dengan teknik seleksi memberikan harapan baru untuk tujuan pemuliaan atau perakitan tanaman [10]. Meskipun penelitian di bidang iradiasi tanaman relatif terbatas, sampai dengan tahun 2000 Indonesia telah menghasilkan 6 varietas mutan padi, 3 mutan kedelai, 1 mutan kacang hijau, dan 1 mutan tembakau. Jumlah varietas mutan yang dihasilkan di dunia mencapai 2.252 kultivar, 1.585 kultivar diperoleh langsung 
setelah dimutasi dan diseleksi pada turunan selanjutnya [10].

Teknik iradiasi yang digunakan untuk peningkatan variasi telah banyak dilakukan mulai dari mikroalga hingga tumbuhan tingkat tinggi. Pemberian iradiasi pada Nannochloropsis sp. iradiasi mampu meningkatkan kandungan lipid [11], Padi [12]. Peningkatkan ketahanan tanaman terhadap cekaman abiotik telah banyak dilakukan pada berbagai tanaman jagung [13][14], dan [15] untuk mendapatkan kalus yang memiliki sifat ketahan terhadap cekaman salinitas. Oleh karena itu, hal tersebut mendasari peneliti untuk melakukan penelitian yang bertujuan untuk mendapatkan informasi mengenai pengaruh iradiasi terhadap perkecambahan benih kedelai varietas Anjasmoro pada kondisi cekaman genangan.

\section{II.METODE PENELITIAN}

\section{A. Waktu dan Tempat Penelitian}

Penelitian ini dilaksanakan di Greenhouse dan Laboratorium Biosains dan Teknologi Tumbuhan, Departemen Biologi, Fakultas Ilmu Alam, Institut Teknologi Sepuluh Nopember (ITS). Penelitian ini dilaksanakan pada bulan Desember 2017 - Januari 2018.

\section{B. Prosedur Kerja}

Penelitian dilakukan sesuai dengan metode sebagai berikut:

\section{1) Persiapan Biji dan Iridiasi benih}

Biji kedelai varietas Anjasmoro diperoleh dari Balai Penelitian Tanaman Kacang - kacangan dan Umbi - umbian (BALITKABI), Kendal Payak - Malang. Sebanyak 500 biji direndam pada larutan Ethanol 70\%, selama 10 menit. Kemudian dilanjutkan dengan melakukan perendaman pada larutan $\mathrm{NaOCl} 1 \%$ selama 2 menit. Selanjutnya biji diletakkan pada cawan petri dan diwrapping. Kemudian dilakukan pemaparan sinar Gama pada beberapa level yaitu 0 Gy, 25 Gy, 50 Gy, 75 Gy, 100 Gy yang dilakukan di Badan Teknologi Atom Nasional (BATAN).

\section{2) Penyemaian Benih}

Biji kedelai yang telah dipapar sinar Gamma ditanam pada media yang telah disiapkan untuk proses penyemaian. Bahan yang digunakan meliputi tanah, pupuk organik, arang sekam, air dan potray. Alat meliputi sekop, bak dan timbangan. Langkah yang dilakukan adalah biji kedelai varietas Anjasmoro hasil iradiasi direndam selama 6 jam menggunakan aquadest kemudian ditiriskan. Hal ini bertujuan untuk mempercepat proses imbibisi sehingga pertumbuhan tunas akan berlangsung lebih cepat. Biji yang telah direndam dan ditiriskan selanjutnya ditumbuhkan di potray berisi media tanam dengan komposisi $2 \mathrm{~kg}$ tanah taman, $0,5 \mathrm{~kg}$ arang sekam dan 0,5 $\mathrm{kg}$ pupuk organik kemudian disemai hingga muncul 2 daun. Biji ditanam sebanyak 20 biji tiap ulangan.

3) Uji Viabilitas dan Vigoritas Benih

Parameter viabilitas yang digunakan dalam penelitian ini adalah :

a. Daya Berkecambah

Daya berkecambah ditentukan dengan menghitung jumlah benih yang berkecambah normal selama jangka waktu 7 hari dengan menggnakan rumus ISTA, [16] sebagai berikut

$$
\mathrm{DK}=\frac{\mathrm{JK}}{\mathrm{JC}} \times 100 \%
$$

Keterangan:

$\mathrm{DK}=$ Daya perkecambahan

$\mathrm{JK}=$ Jumlah kecambah normal yang dihasilkan

$\mathrm{JC}=\mathrm{Jumlah}$ contoh benih yang diujikan

b. Laju Perkecambahan

Laju perkecambahan dihitung dengan menggunakan rumus menurut Sadjad dkk., dalam Sutopo [17]sebagai berikut :

$$
\mathrm{LP}=\frac{\mathrm{N} 1 \mathrm{~T} 1+\mathrm{N} 2 \mathrm{~T} 2+\cdots+\mathrm{NXTX}}{\mathrm{JB}}
$$

Keterangan :

LP = Laju Perkecambahn

$\mathrm{N}=$ Jumlah benih yang berkecambah pada satuan waktu

$\mathrm{T}=$ Jumlah waktu antara pengujian awal sampai pengujian akhir pada interval tertentu

$\mathrm{JB}=$ Jumlah benih yang berkecambah

Parameter vigoritas yang diukur adalah keserempakan tumbuh benih (\%). Keserempakan tumbuh benih dihitung dengan menggunakan presentase kecambah normal kuat pada hari ke 4. Menurut Sadjad [18] parameter vigoritas dapat dihitung dengan rumus sebagai berikut :

$$
\mathrm{Kst}=\frac{\mathrm{KK}}{\mathrm{TB}} \times 100 \%
$$

Keterangan :

Kst $=$ Keserempakan tumbuh

$\mathrm{KK}=$ Jumlah kecambah normal kuat

$\mathrm{TB}=$ Total benih yang dianalisis

\section{4) Tahap Aklimatisasi}

Pembuatan media tanam dilakukan dengan menyiapkan tanah taman, pupuk organik dan arang sekam. Setiap polybag memiliki komposisi $2 \mathrm{~kg}$ tanah taman, $0,5 \mathrm{~kg}$ arang sekam dan $0,5 \mathrm{~kg}$ pupuk organik sehingga didapatkan berat total sebanyak $3 \mathrm{~kg} /$ polybag. Media tanam yang telah ditimbang diaduk secara merata untuk selanjutnya dimasukkan kedalam polybag dan di beri label sesuai perlakuan. Proses aklimatisasi tanaman kedelai (Glycine max) dilakukan selama 10 hari. Aklimatisasi bertujuan untuk adaptasi tanaman kedelai (Glycine max) terhadap media baru. Pemeliharaan yang dilakukan adalah penyiraman. Penyiraman dilakukan pada saat proses penyemaian dan aklimatisasi secara teratur pada pagi dan sore hari sesuai kebutuhan [19].

\section{5) Pengukuran Kapasitas Lapang Media Tanam}

Pengukuran kapasitas lapang bertujuan unuk menentukan volume penyiraman sebagai patokan pemberian taraf penggenangan yaitu dengan cara media tanam dalam polybag disiram dengan air sampai menetes (jenuh) kemudian didiamkan selama kurang lebih 3 hari sampai tidak ada air yang menetes. Selanjutnya, media tanam ditimbang berat basah dan berat keringnya. Berat basah ditimbang setelah tidak ada air yang menetes dari polybag. Berat kering ditimbang setelah media tanam dioven pada suhu $105^{\circ} \mathrm{C}$ sampai diperoleh berat konstan [19]. Kebutuhan Air berdasarkan Kapasitas Lapangnya dihitung dengan rumus sebagai berikut: 


$$
\mathrm{KL}(\%)=\frac{\mathrm{Tb}-\mathrm{Tl}}{\mathrm{Tk}} \times 100 \%
$$

Keterangan :

KL : Kapasitas Lapang

$\mathrm{Tb}$ : Berat Basah Tanah

Tk : Berat Kering Tanah

\section{6) Tahap Seleksi Genangan}

Tanaman kedelai yang telah di aklimatisasi selama 10 hari selanjutnya diberi perlakuan cekaman genangan. Penggenangan dilakukan selama 14 hari pada semua taraf perlakuan dengan cara memberikan air ke dalam masingmasing polybag sebanyak konsentrasi yang telah ditentukan berdasar pada hasil penelitian pendahuluan kapasitas lapang. Setiap tanaman diberi cekaman genangan dengan lima perbedaan konsentrasi genangan yaitu kontrol, 100\%, 150\%, $200 \%$ dan $250 \%$ [19].

\section{7) Pengamatan Pertumbuhan Tanaman Kedelai}

Pemanenan tanaman kedelai dilakukan setelah lebih kurang 14 hari perlakuan cekaman genangan. Tanaman pada tiap-tiap perlakuan diambil dan dibersihkan dari sisa tanah menggunakan air kemudian dikeringkan. Selanjutnya, Tanaman dimasukkan ke dalam plastik ziplock dan diberi label. Kemudian disimpan dalam freezer untuk selanjutnya di lakukan analisis.

\section{a. Tinggi Tanaman ( $\mathrm{cm})$}

Pengukuran terhadap tinggi tanaman dilakukan pada sebelum dan setelah tahap seleksi genangan ( $\Delta$ tinggi tanaman). Tinggi tanaman kedelai diukur dari pangkal batang sampai ujung daun (pucuk) [20].

\section{b. Luas Daun}

Pengukuran terhadap luas daun dilakukan setelah proses pemberian cekaman genangan selama 14 hari dengan metode gravimetri, yaitu dengan cara menggambar daun yang akan ditaksir luasnya pada selembar kertas. Luas daun dihitung berdasarkan perbandingan berat replika daun dengan berat total kertas. Sampel daun yang digunakan diambil dari buku yang sama pada tiap perlakuan [19]. Adapun rumus perhitungannya adalah sebagai berikut [21]:

Keterangan:

$$
\mathrm{LD}=\frac{\mathrm{Wr}}{\mathrm{Wt}} \times{ }_{\mathrm{LK}}
$$

$\mathrm{LD}=$ luas daun

$\mathrm{Wr}=$ berat kertas replika daun $(\mathrm{g})$

$\mathrm{Wt}=$ berat total kertas $(\mathrm{g})$

LK = luas total kertas

\section{Rancangan Penelitian}

Penelitian ini dirancang dengan menggunakan Rancangan Acak Lengkap (RAL). Rancangan Acak Lengkap yang disusun dengan percobaan faktorial yang terdiri dari 1 faktor. Faktor pertama adalah pemberian dosis iradiasi sinar gamma yang terdiri dari 5 tingkatan yaitu $0 \mathrm{~Gy}, 25 \mathrm{~Gy}, 50$ Gy dan 75 Gy dan 100 Gy. Setiap perlakuan dikombinasikan dengan 3 ulangan

\section{D.Analisis Data}

Data dianalisis dengan analisis keragaman ANOVA One Way untuk mengetahui pengaruh faktor perlakuan iradiasi sinar gamma terhadap vigoritas dan viabilitas benih dan
ANOVA two way untuk mengetahui faktor iradiasi dan genangan terhadap morfologi tanaman, Hasil uji Anova tersebut dilanjutkan dengan uji Duncan Multiple Range Test (DMRT) taraf kepercayaan 95\%.

\section{HASIL DAN PEMBAHASAN}

\section{A. Viabilitas dan Vigoritas Benih Kedelai (Glycine max L.)}

Pengukuran viabilitas dan vigoritas digunakan sebagai indikator penting terkait dengan kualitas benih. Vigoritas digambarkan melalui kemampuan tumbuh benih, secara fisiologis benih tersebut dapat tumbuh menjadi normal meskipun keadaan dilapangan tidak optimal [22]. Sedangkan viabilitas benih diartikan sebagai kemampuan benih untuk tumbuh menjadi kecambah yang dapat ditunjukkan melalui gejala metabolisme atau gejala pertumbuhan [23].

Benih kedelai varietas Anjasmoro hasil iradiasi direndam selama 6 jam menggunakan aquadest kemudian ditiriskan. Hal ini bertujuan untuk mempercepat proses imbibisi sehingga pertumbuhan tunas akan berlangsung lebih cepat. Benih yang telah direndam dan ditiriskan selanjutnya ditumbuhkan di potray berisi media tanam dengan komposisi $2 \mathrm{~kg}$ tanah taman, $0,5 \mathrm{~kg}$ arang sekam dan $0,5 \mathrm{~kg}$ pupuk.

Pada pengujian ini didapatkan persentase benih normal, benih abnormal, dan benih segar tidak tumbuh (Gambar 1). Ciri benih normal adalah memiliki akar primer yang kuat dan panjang, plumula berwarna hijau, perkembangan hipokotil sempurna, benih abnormal tidak memiliki akar primer, plumula membusuk, sedangkan ciri benih segar tidak tumbuh adalah benih yang tidak tumbuh sampai akhir dari pengujian, tetapi masih mempunyai kemampuan untuk tumbuh menjadi normal. Benih jenis ini mampu menyerap air selama proses pengujian tetapi mengalami hambatan untuk prose perkembangan selanjutnya [24].

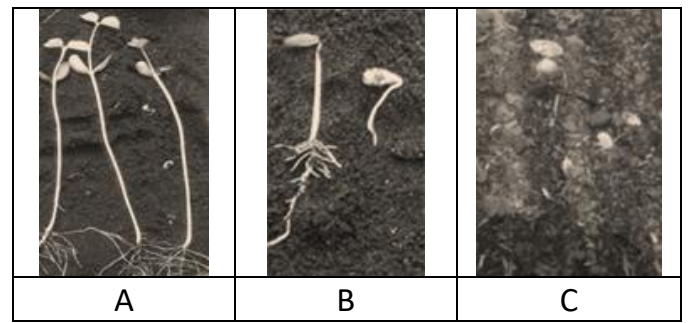

Gambar 1. Macam Kategori Kecambah

Keterangan : A) Kecambah normal, B) Kecambah abnormal, C) Benih segar tidak tumbuh.

Dampak awal timbulnya mutasi pada suatu tanaman dapat dilihat melalui perkecambahan. Radiasi menyebabkan kerusakan pada tingkat kromosom dan DNA benih yang akan mempengaruhi fisiologis dan biokimia pada tanaman. Semakin tinggi dosis iradiasi yang diberikan maka benih akan mengalami peningkatan kadar protein dan penurunan kadar karbohidrat total serta energi total. Kadar karbohidrat dan energi total yang rendah membuat kecambah menjadi abnormal dan proses perkecambahan menjadi terhambat [25] Menurut Amjad dan Akbar [26] pada percobaan iradiasi pada benh Allium cepa L., iradiasi pada dosis tinggi menyebabkan presentase bibit abnormal meningkat seiring dengan peningkatan dosis iradiasi. 
Berdasarkan SNI 01-6234.2-2003 daya berkecambah benih kedelai memiliki batas minimum sebesar $80 \%$ sehingga dapat disikatakan benih kedelai varietas Anjasmoro pada dosis 0 Gy (kontrol), 25 Gy, 50 Gy dan 75 Gy masih dalam batas standar ketentuan SNI (Tabel 4.1). Sedangkan pada dosis 100 Gy memiliki hasil daya berkecambah dibawah batas minimum SNI. SNI 01-6234.2-2003 digunakan sebagai acuan normatif, syarat mutu dan rekomendasi untuk benih kedelai.

Tabel 1.

Pengaruh Dosis Iradiasi terhadap Parameter daya berkecambah, laju perkecambahan dan Keserempakan Tumbuh Benih Kedelai Varietas Anjasmoro pada Kecambah Normal

\begin{tabular}{cccc}
\hline \hline Dosis & \multicolumn{3}{c}{ Parameter } \\
\cline { 2 - 4 }$($ Gy) & $\begin{array}{c}\text { Daya } \\
\text { Berkecambah } \\
(\%)\end{array}$ & $\begin{array}{c}\text { Laju } \\
\text { Perkecambahan } \\
\text { (hari) }\end{array}$ & $\begin{array}{c}\text { Keserempakkan } \\
\text { Tumbuh }(\%)\end{array}$ \\
\hline 0 & $93,33 \mathrm{ab}$ & $3,8 \mathrm{a}$ & $80 \mathrm{a}$ \\
25 & $98,33 \mathrm{a}$ & $4 \mathrm{a}$ & $80 \mathrm{a}$ \\
50 & $98,33 \mathrm{a}$ & $4,3 \mathrm{a}$ & $70 \mathrm{ab}$ \\
75 & $86,67 \mathrm{bc}$ & $4,3 \mathrm{a}$ & $73,33 \mathrm{ab}$ \\
100 & $78,33 \mathrm{c}$ & $4,3 \mathrm{a}$ & $68,33 \mathrm{~b}$ \\
\hline \hline
\end{tabular}

Keterangan : angka-angka yang diikuti huruf yang berbeda pada kolom yang sama menunjukkan beda nyata berdasarkan uji DMRT pada taraf kepercayaan $95 \%$.

Rerata daya berkecambah yang terdapat pada Tabel 1 menunjukkan bahwa peningkatan dosis iradiasi memberikan pengaruh yang berbeda nyata (nilai $\mathrm{p}=0.002$; taraf $95 \%$ ) pada presentase daya berkecamabah kedelai varietas Anjasmoro selama tujuh hari. Daya berkecambah benih kedelai varietas Anjasmoro memperlihatkan hasil beragam dimana pada dosis 25 Gy dan 50 Gy didapatkan hasil daya berkecambah tertinggi yang sama sebesar 98,33\%. Sedangkan daya berkecambah terendah pada dosis $100 \mathrm{~Gy}$ sebesar 78,33\% (Tabel 1). Menurut Aisyah et al., [27]; Dwimahyani [28]; Srivastava [29] meningkatnya dosis iradiasi yang diberikan pada benih kedelai, maka akan menurunkan daya berkecambah benih.

Peningkatan perkecambahan biji pada dosis rendah meningkatkan penyerapan oksigen sehingga dapat berpengaruh langsung untuk mematahkan dormansi [30]. Iradiasi sinar gamma juga berperan dalam menstimulus aktivasi RNA atau sintesis protein yang berlangsung pada tahap awal perkecambahan ketika benih telah di iradiasi. Penurunan daya berkecambah dapat disebabkan karena pengaruh iradiasi sinar gamma yang dapat meningkatkan cekaman oksidatif sehingga menyebabkan perubahan konformasi, oksidasi, pelepasan ikatan kovalen dan terbentuknya radikal bebas seperti hidroksil dan anion superoksida yang timbul dari adanya pemaparan iradiasi [31]. Perubahan kimiawi tersebut akan langsung bereaksi dengan semua molekul organik secara struktural dan fungsional termasuk protein, lipid, dan asam nukleat menyebabkan terganggunya metabolisme sel. Salah satunya mempengaruhi aktivitas enzim seperti menurunnya aktivitas enzim lipase dengan meningkatnya dosis iradiasi sinar gamma pada biji jarak [32].

Selain pengujian daya berkecambah, pengujian juga dilakukan terhadap laju perkecambahan Berdasarkan hasil yang terdapat pada Tabel 1 menunjukkan bahwa peningkatan dosis memberikan pengaruh yang tidak berbeda nyata (nilai $\mathrm{p}=0.151$; taraf $95 \%$ ) pada laju perkecambahan kedelai varietas Anjasmoro. Pada hasil laju perkecambahan, terlihat bahwa peningkatan dosis iradiasi memberikan pengaruh namun pengaruh yang diberikan tidak signifikan. Terjadi penurunan laju perkecambahan sering dengan meningkatnya dosis iradiasi pada benih kedelai varietas Anjasmoro. Hal ini dapat dilihat dari semakin lamanya waktu yang dibutuhkan oleh kedelai varietas Anjasmoro untuk berkecambah. Pada dosis kontrol perkecambahan membutuhkan 25 Gy perkecambahan membutuhkan waktu 4 hari dan pada dosis $50 \mathrm{~Gy}, 75$ Gy dan $100 \mathrm{~Gy}$ membutuhkan waktu 4 hari 3 jam.

Pada dosis 50 Gy, 75 Gy dan 100 Gy diperoleh hasil laju perkecambahan dengan nilai tertinggi yang berarti benih membutuhkan waktu lebih lama untuk menumbuhkan radikula. Dosis tinggi secara langsung menurunkan laju perkecambahan dalam mekanisme perkembangan plumula atau akar [33]. Penambahan dosis iradiasi menunjukkan bahwa

perkecambahan biji dapat ditingkatkan dengan iradiasi dosis rendah, dimana iradiasi dosis tinggi dapat menghambat perkecambahan dan berkorelasi secara langsung dengan laju perkecambahan [34]. Beberapa penelitian yang telah dilakukan oleh Iqbal et al., [34], Thapa et al., [35] dan Khawar et al., [36] menunjukkan bahwa pemaparan iradiasi dengan dosis yang tinggi umumnya menghambat perkecambahan biji dimana pemaparan dengan dosis rendah cenderung meningkatkan perkecambahan. Stimulasi yang ditimbulkan dari sinar gamma pada perkecambahan diperkirakan dari aktivasi RNA untuk sintesis protein, dimana terjadi pada tahap awal perkecambahan setelah biji di iradiasi [37].

Menurut Nepal, et al., [38] radiasi meningkatkan sensitivitas tanaman dengan mereduksi jumlah zat pengatur tumbuh endogenus terutama sitokinin dengan cara mendegradasi atau menurunkan tingkat sintesisnya. Iradiasi sinar gamma tidak secara langsung menurunkan akumulasi sitokinin, namun iradiasi mempengaruhi degradasi sel dan sintesis sitokinin. Berdasarkan Shukla, et al., [39]sintesis sitokinin membutuhkan fungsi optimal dari organel sel mitokondria untuk menghasilkan ATP dan menyediakan kalsium sehingga m-RNA dapat berperan sebagai template sintesisnya. Iradiasi dapat mendegradasi mitokondria dan nukleus karena membran sel dan membran nukleus sensitif terhadap paparan iradiasi, namun sitokonin yang telah diakumulasi dalam granula tidak akan mengalami degradasi karena granula memeiliki struktur sel yang resisten terhadap iradiasi.

Biji kedelai dari varietas yang telah dibudi dayakan umumnya mampu melakukan imbibisi setelah biji ditanam pada kondisi tanah yang lembab. Namun pada varietas kedelai liar, sering ditemukan adanya biji keras yang memperlambat penyerapan/pengambilan air. Garis terang (light line) yang terdapat pada sel epidermis diduga menjadi penyebab kejadian tersebut, sekaligus menjadi penentu tingkat impermeabilitas biji. Air berimbibisi melalui keseluruhan permukaan biji, termasuk daerah hilum dan mikrofil. Setelah kulit biji dan embrio berimbibisi maksimal, 
biji akan kehilangan bentuk ovalnya dan berubah bentuk menyerupai bentuk ginjal [40].

Apabila kondisi kelembaban dan suhu sesuai, calon akar akan muncul dari kulit biji yang retak di daerah mikrofil dalam 1-2 hari. Pertumbuhan calon akar ke dalam tanah terjadi sangat cepat dan ketika mencapai panjang 2-3 cm, cabang akar pertama akan muncul. Kotiledon terangkat ke atas tanah akibat pertumbuhan hipokotil, selanjutnya bagian atas hipokotil mencapai permukaan tanah terlebih dahulu dan mendorong kotiledon dari dalam tanah, sekaligus kulit bijinya (Gambar 2). Pertumbuhan hipokotil mengangkat kotiledon yang kemudian menjadi hijau. Selama tahapan awal pertumbuhan kecambah, kotiledon membawa hasil fotosintesis sebagai tambahan untuk memasok mineral tersimpan dan cadangan makanan pada proses perkecambahan hingga daun dan akar terbentuk sempurna. Akhirnya, kotiledon menguning dan rontok dari tanaman [40].

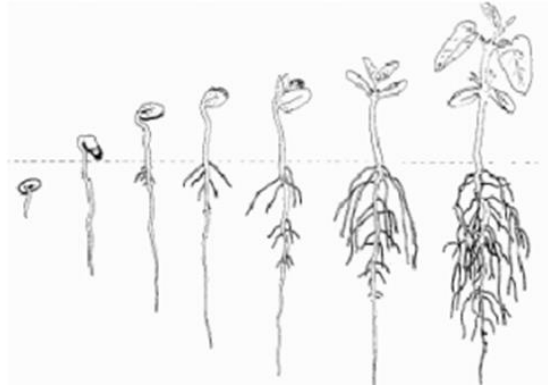

Gambar 2. Tahap Perkecambahan Biji Kedelai.

Setelah dilakukan pengujian terhadap viabilitas benih, pengujian dilakukan terhadap vigoritas benih. Keserempakan tumbuh benih merupakan satu parameter pengujian vigoritas benih. Terlihat bahwa rata-rata benih serempak tumbuh pada hari ke 4 dalam 7 hari penanaman, sehingga keserempakkan tumbuh benih dihitung dengan menggunakan presentase kecambah normal kuat pada hari ke 4. Berdasarkan hasil yang terdapat pada tabel 1 menunjukkan bahwa peningkatan dosis memberikan pengaruh yang tidak berbeda nyata (nilai $\mathrm{p}=0.092$; taraf 95\%) pada presentase keserempakkan tumbuh benih kedelai varietas Anjasmoro selama 7 hari. Berdasarkan hasil pengamatan kesrempakkan tumbuh benih, terlihat bahwa peningkatan dosis iradiasi memberikan pengaruh namun pengaruh tersebut tidak signifikan. Terjadi penurunan keserempakkan tumbuh benih seiring dengan meningkatnya dosis iradiasi pada benih kedelai varietas Anjasmoro. Pada dosis 25 Gy keserempakkan benih sama dengan benih yang tidak di iriadiasi yaitu sebesa $80 \%$, namun pada dosis 50,75 dan 100 Gy terjadi penurunan sebesar 70, 73.33 dan 68.33 berturut-turut. Tingginya keserempakkan tumbuh benih kedelai varietas Anjasmoro dapat dipengaruhi oleh paparan cahaya yang merata.

Menurunnya keserempakkan tumbuh benih berkaitan dengan efek umum radiasi yang sering ditunjukkan dengn kerusakan fisiologi seperti hambatan pertumbuhan, kematian dan sterilitas tanaman [41]. Selain kerusakan fisiologis, terdapat efek deterministik akibat iradiasi sinar gamma. Menurut Utami [42], efek deterministik adalah efek yang disebabkan karena kematian sel akibat paparan radiasi. Efek deterministik terjadi apabila dosis yang diterima tanaman diatas dosis ambang (threshold dose) dan umumnya timbul beberapa saat setelah iradiasi. Tingkat keparahan efek deterministik akan meningkat bila dosis yang diterima lebih besar dari dosis ambang.

Ketidak seragaman tumbuh dapat diakibatkan oleh sifat genetik yang tidak sama, atau kondisi lingkungan yang tidak homogen [43]. Keserempakkan tumbuh benih yang ditanaman baik pada media uji di laboratorium atau dilahan berkaitan dengan kemampuan benih secara berkelompok untuk memanfaatkan cadangan energy dalam masing-masing benih untuk tumbuh menjadi kecambah atau kuat secara serempak [43]. Pada umumnya benih dengan nilai vigor rendah kurang bias memanfaatkan energi dibandingan dengan nilai vigor tinggi [43]. Menurut Syarifuddin dan Miranda [44], vigor benih yang tinggi menyebabkan benih toleran tumbuh dan berkembang pada kondisi lahan yang sub-optimum berupa lingkungan yang kurang sesuai untuk pertumbuhan dan perkecambahan benih. Keserempakkan benih yang baik berkisar antar $40 \%-70 \%$, dengan nilai keserempakkan berkiasar diatas 80\%-68.33\% maka dapat dikatakan benih kedelai varietas Anjasmoro memiliki nilai vigor yang tinggi [43].

\section{B. Pengaruh Cekaman Genangan Terhadap Pertumbuhan Tanamna Kedelai (Glycine max. L).}

Pertumbuhan tanaman digunakan sebagai indikator untuk mengetahui karakteristik tanaman dan hubungannya dengan faktor lingkungan [45]. Ketersediaan air merupakan faktor yang dapat mempengaruhi pertumbuhan dan perkembangan suatu tanaman karena kekurangan maupun kelebihannya berpengaruh terhadap proses metabolisme [46].

Tabel 2.

Hasil Pengamatan Rerata Pertumbuhan Tinggi Tanaman $(\mathrm{Cm})$ Kedelai Varietas Anjasmoro Pada Berbagai Dosis Iradiasi Sinar Gamma Sebelum dan Setelah Perlakuan Cekaman Genangan

\begin{tabular}{llllll}
\hline \hline \multirow{2}{*}{$\begin{array}{l}\text { Dosis } \\
\text { Iradiasi }\end{array}$} & \multicolumn{5}{c}{ Konsentrasi Genangan } \\
\cline { 2 - 6 } Kontrol & $\mathbf{1 0 0 \%}$ & $\mathbf{1 5 0 \%}$ & $\mathbf{2 0 0 \%}$ & $\mathbf{2 5 0 \%}$ \\
\hline \multirow{2}{*}{$0 \mathrm{~Gy}$} & $101.66 \pm$ & $71.00 \pm$ & $62.33 \pm$ & $57.00 \pm$ & $40.33 \pm$ \\
& $53.50 \mathrm{a}$ & $22.91 \mathrm{a}$ & $34.48 \mathrm{a}$ & $52.43 \mathrm{a}$ & $14.84 \mathrm{a}$ \\
\multirow{2}{*}{$25 \mathrm{~Gy}$} & $104.66 \pm$ & $102.33 \pm$ & $93.66 \pm$ & $67.33 \pm$ & $51.33 \pm$ \\
& $28.98 \mathrm{a}$ & $64.60 \mathrm{a}$ & $15.01 \mathrm{a}$ & $14.36 \mathrm{a}$ & $15.04 \mathrm{a}$ \\
\multirow{2}{*}{$50 \mathrm{~Gy}$} & $84.66 \pm$ & $81.00 \pm$ & $71.33 \pm$ & $61.33 \pm$ & $47.66 \pm$ \\
& $15.82 \mathrm{a}$ & $54.24 \mathrm{a}$ & $11.59 \mathrm{a}$ & $35.23 \mathrm{a}$ & $24.40 \mathrm{a}$ \\
\multirow{2}{*}{$75 \mathrm{~Gy}$} & $83.66 \pm$ & $79.33 \pm$ & $64.66 \pm$ & $46.66 \pm$ & $40.66 \pm$ \\
& $19.13 \mathrm{a}$ & $9.29 \mathrm{ab}$ & $10.01 \mathrm{abc}$ & $21.38 \mathrm{bc}$ & $24.94 \mathrm{c}$ \\
\multirow{2}{*}{$100 \mathrm{~Gy}$} & $81.33 \pm$ & $78.00 \pm$ & $50.00 \pm$ & $45.00 \pm$ & $32.33 \pm$ \\
& $6.50 \mathrm{a}$ & $6.55 \mathrm{a}$ & $48.4 \mathrm{a}$ & $28.61 \mathrm{a}$ & $22.05 \mathrm{a}$ \\
\hline \hline
\end{tabular}

Keterangan : rerata yang diikuti dengan huruf yang sama tidak menunjukkan adanya perbedaan yang signifikan $(\mathrm{p}<0,05)$. Angka dibelakang tanda \pm merupakan Standar Deviasi (STD).

Berdasarkan tabel 2 diketahui bahwa dosis iradiasi $0 \mathrm{~Gy}$, 25 Gy, 50 Gy, 75 Gy dan 100 Gy dengan seluruh perlakuan genangan tidak berbeda nyata. Nilai rerata tinggi tanaman tertinggi terdapat pada perlakuan iradiasi 25 Gy pada kontrol (tanpa genangan) dan terendah pada iradiasi 100 Gy genangan 250\%. Hal ini dapat dikatakan bahwa pertumbuhan tinggi tanaman mengalami penurunan seiring dengan meningkatnya dosis iradiasi sinar gamma. Penurunan tinggi tanaman tersebut dapat terjadi karena iradiasi dapat menyebabkan rusaknya kromosom tanaman, sehingga mengakibatkan terganggunya tanaman tersebut. Ionisasi 
akibat iradiasi dapat menyebabkan pengelompokan molekul - molekul sepanjang jalur ion yang tertinggal karena iradiasi yang dapat menyebabkan mutasi gen atau kerukan kromosom [27].

Kemampuan peningkatan tinggi tanaman tergantung pada sifat genetik varietas dan dipengaruhi oleh lingkungan atau tingkat perkembangan tanaman sebelum penggenangan [47][48].

Sel- sel meristem pucuk dari tanaman yang diiradiasi dengan dosis yang tinggi diduga mengalami kerusakan. Hal ini sesuai dengan penelitian Ramesh et al. [49] pada tanaman mulberry bahwa iradiasi sinar gamma menyebabkan terhambatnya sintesis auksin dan pembelahan sel.

Penelitian Aisyah et al. [27] pada stek pucuk anyelir menyatakan bahwa iradiasi sinar gamma dosis 15 Gy berpengaruh nyata terhadap penurunan tinggi tanaman. Dwimahyani [28] pada stek pucuk krisan yang diiradiasi sinar gamma (dosis 0, 10, 15, 20, dan 25 Gy), yang menghasilkan pertumbuhan tanaman yang cenderung menurun dengan semakin besarnya dosis iradiasi sinar gamma. Hal ini terjadi karena terjadi kerusakan fisiologis akibat sinar gamma. Menurut Srivastava dan Kumar [29] semakin tinggi dosis radiasi sinar gamma yang diberikan, tanaman safflower semakin pendek bila dibandingkan dengan tanaman kontrol, karena iradiasi sinar gamma menyebabkan terjadinya gangguan pada sintesis DNA.

Pada perlakuan iradiasi 0 Gy semakin meningkat konsentrasi genangan maka tanaman cendurung mengalami penurunan tinggi tanaman. Cekaman genangan mengakibatkan turunnya pasokan oksigen sehingga aktifitas metabolisme tanaman menjadi terhambat dan menyebabkan reduksi tinggi tanaman [50]. Pada perlakuan iradiasi 25 Gy memiliki tinggi tanaman tertinggi. Hal ini dimungkinkan karena dosis iradiasi 25 Gy merupakan iradiasi sinar gamma dosis rendah. Dosis iradiasi sinar gamma dengan dosis rendah dapat dijadikan sebagai perlakuan benih (seed treatment) yang mampu memperbaiki perkecambahan dan pertumbuhan benih [23]. Selain itu, penggenangan menyebabkan nutrien menjadi lebih tersedia bagi tanaman yang kemudian digunakan tanaman untuk pertumbuhannya yang ditunjukkan dengan meningkatnya tinggi tanman. Hal ini juga didukung oleh pernyatan [51] bahwa genangan meningkatkan ketersediaan nutrien yang dibantu oleh aktivitas mikrobia. Ketersediaan hara yang optimal memberikan kontribusi pada pertumbuhan tanaman. Selain itu menurut penelitian Kawano et al., [48] bahwa adanya genangan akan memacu pemanjangan batang sebagai salah satu strategi penghindaran (escape strategy) terhadap penggenangan untuk membantu kebutuhan oksigen dan karbondioksida untuk mendukung respirasi aerob dan fotosintesis [52].

Etilen merupakan salah satu hormon yang menstimulus adanya percepatan pemanjangan sel saat tanaman berada dalam kondisi tergenang. Etilen tidak memacu pertumbuhan batang secara langsung tetapi melalui aksi giberelin. Selama penggenangan kondisi lingkungan dengan konsentrasi $\mathrm{CO}_{2}$ dan cahaya yang rendah menyebabkan reduksi kemampuan fotosintesis pada tanaman yang tergenang. Karbohidrat terutama sebagai suplai energi untuk memelihara metabolisme selama penggenangan [53]. Fungsi etilen tidak hanya berperan dalam elongasi sel tetapi juga pembelahan sel [54]. Berikut adalah gambar pertumbuhan tinggi tanaman kedelai varietas Anjasmoro pada perlakuan iradiasi dan penggenangan yang berbeda.

Tabel 3.

Hasil Pengamatan Rerata Luas Daun $\left(\mathrm{Cm}^{2}\right)$ Tanaman Kedelai Varietas Anjasmoro Setelah Perlakuan Cekaman Genangan

\begin{tabular}{|c|c|c|c|c|c|}
\hline \multirow{2}{*}{$\begin{array}{l}\text { Dosis } \\
\text { Iradiasi }\end{array}$} & \multicolumn{5}{|c|}{ Konsentrasi Genangan } \\
\hline & Kontrol & $100 \%$ & $150 \%$ & $200 \%$ & $250 \%$ \\
\hline \multirow[t]{3}{*}{$0 \mathrm{~Gy}$} & 23.09 & 20.54 & 17.59 & 13.02 & 10.07 \\
\hline & \pm & \pm & \pm & \pm & \pm \\
\hline & $2.46 a$ & $2.24 \mathrm{a}$ & $3.52 \mathrm{ab}$ & $52.58 \mathrm{c}$ & $42.06 \mathrm{c}$ \\
\hline \multirow[t]{3}{*}{$25 \mathrm{~Gy}$} & 22.42 & 17.19 & 16.51 & 12.35 & 9.93 \\
\hline & \pm & \pm & \pm & \pm & \pm \\
\hline & $5.47 \mathrm{a}$ & $3.47 \mathrm{ab}$ & $3.84 \mathrm{abc}$ & $2.55 \mathrm{bc}$ & $1.90 \mathrm{c}$ \\
\hline \multirow[t]{3}{*}{50 Gy } & 28.87 & 23.77 & 18.93 & 13.02 & 12.57 \\
\hline & \pm & \pm & \pm & \pm & \pm \\
\hline & $10.60 \mathrm{a}$ & $11.36 \mathrm{a}$ & $9.50 \mathrm{a}$ & $10.58 \mathrm{a}$ & $3.12 \mathrm{a}$ \\
\hline \multirow[t]{3}{*}{75 Gy } & 20.68 & 18.93 & 18.66 & 17.86 & 11.28 \\
\hline & \pm & \pm & \pm & \pm & \pm \\
\hline & $9.52 \mathrm{a}$ & $3.62 \mathrm{a}$ & $10.13 \mathrm{a}$ & $0.93 a$ & $3.04 \mathrm{a}$ \\
\hline \multirow[t]{3}{*}{$100 \mathrm{~Gy}$} & 20.27 & 14.90 & 14.10 & 12.22 & 9.26 \\
\hline & \pm & \pm & \pm & \pm & \pm \\
\hline & $14.10 \mathrm{a}$ & $4.08 \mathrm{a}$ & $4.75 a$ & $0.46 \mathrm{a}$ & $4.43 \mathrm{a}$ \\
\hline
\end{tabular}

Berdasarkan tabel 3, diketahui bahwa dosis iradiasi 0 Gy, 25 Gy, 50 Gy, 75 Gy dan 100 Gy dengan seluruh perlakuan genangan tidak berbeda nyata. Nilai rerata luas daun tertinggi terdapat pada perlakuan iradiasi 50 Gy pada kontrol (tanpa genangan) dan terendah pada iradiasi 100 Gy genangan $250 \%$. Dosis iradiasi rendah yang digunakan pada biji, umbi-umbian, dan spora dilaporkan dapat mempercepat proses perkecambahan, mempercepat proses pertumbuhan, dan meningkatkan hasil akhir pada saat dipanen. Sebaliknya, dosis yang tinggi akan mengakibatkan adanya penghambatan pertumbuhan atau bahkan letal pada tanaman [55]. Iradiasi adalah transmisi energy melalui material atau ruang dalam bentuk panas, partikel atau gelombang elektromagnetik (foton) dari sumber energy. Iradiasi dapat menyebabkan mutasi karena sel-sel akan diiradiasi dibebani oleh energi kinetik yang tinggi, sehingga dapat mempengaruhi atau mengubah reaksi kimia sel tumbuhan yang bias akhirnya mengarah pada perubahan komposisi kromosom tanaman [56].

Seiring dengan meningkatnya taraf penggenangan luas daun tanaman kedelai hasil iradiasi mengalami penurunan. Penurunan luas daun merupakan salah satu gejala penurunan pertumbuhan tanaman yang dapat diamati ketika tanaman mengalami kondisi hipoksia atau anoksia. Menurut Sena dan Kozlowski [57] pada saat kondisi hipoksia atau anoksia tanaman akan memperlihatkan penurunan sintesis klorofil karena akumulasi etilen dan atau penurunan sintesis sitokinin. Etilen merupakan salah satu kelompok hormon dalam bentuk gas hidrokarbon yang memiliki efek signifikan pada perkembangan tunas dan akar. Peningkatan sisntesis etilen merupakan salah satu bentuk respon tanaman terhadap cekaman dan banyak diproduksi oleh jaringan yang mengalami penuaan atau pematangan [58]

Penelitian pada bunga matahari (Helianthus annus L.) dalam waktu satu hari penggenangan menunjukkan adanya 
konsentrasi hormon sitokinin yang sangat rendah pada pembuluh xilem. Sitokinin merupakan salah satu derivat dari basa nitrogen adenin yang dapat berpengaruh pada proses perkembangan tanaman, termasuk diferensiasi pada kultur jaringan, pertumbuhan tunas lateral, perluasan daun, perkembangan kloroplas, dan penundaan proses penuaan daun [58]. Penurunan sinteis sitokinin pada akar ini disebabkan oleh kondisi hipoksia atau anoksia. Sehingga akar tidak mampu mentranspor sitokinin ke bagian aerial tanaman seperti daun dan batang [59]. Sitokinin disintesis pada meristem apikal akar [60] dimana menjadi tempat paling awal menurunnya aktivitas metabolik dan kematian sel akibat cekaman genangan dari pada jaringan lain [61]. Akibat sitokinin yang rendah pada organ aerial, utamanya daun menyebabkan terhambatnya pembelahan sel. Dalam penelitian ini, diduga adanya penurunan sitokinin endogen pada kedelai varietas Anjasmoro disebabkan karena terjadi penurunan ekspresi gen IPT yang mengkode enzim isopentenil transferase dalam inisiasi dan pembatasan jalur biosintesis sitokinin. Bila dibandingkan dengan kedelai hasil iradiasi 50 Gy dengan konsentrasi genagan $150 \%$ di atas kapasitas lapang menunjukkan hasil rerata paling maksimal, ekspresi gen IPT diduga terjadi secara normal sehingga pertumbuhan daun dapat terjadi secara normal.

\section{KESIMPULAN}

Iradiasi sinar gamma pada benih tanaman kedelai varietas Anjasmoro memberikan pengaruh yang tidak signifikan. Dosis iradiasi tinggi (high irradiation dose) 100 Gy pada benih kedelai menurunkan viabilitas dan vigoritas. Dosis iradiasi 100 Gy dan genangan tinggi 250\% menurunkan morfologi tanaman. Parameter viabilitas vigoritas dan morfologi terbaik terdapat pada dosis iradiasi sinar gamma dengan dosis rendah (low irradiation dose) dimana daya berkecambah terbaik terdapat pada iradiasi 25 Gy dan 50 Gy, laju perkecambahan terbaik terdapat pada perlakuan kontrol, sedangkan keserempakan tumbuh terbaik terdapat pada perlakuan kontrol dan iradiasi 25 Gy. Tinggi tanaman terbaik pada iridiasi 25 Gy pada genangan kontrol dan Luas daun terbaik berada pada iradiasi 50 Gy genangan kontrol.

\section{DAFTAR PUSTAKA}

[1] U. dan Y. Y. Pato, Gizi dan Pangan. Pekanbaru: UNRI Press, 2002.

[2] H. . Suprapto, Bertanam Kedelai. Jakarta: Swadaya, 1999.

[3] A. Michael, "Produksi Kedelai Tahun Ini Diprediksi Sulit Meningkat," detikfinance, 2017.

[4] H. Alam, I., Lee, D.G., Kim, K.H., Park, C.H., Sharmin, S.A., Lee, "Proteome Analysis of Soybean Roots Under Waterlogging Stress at An Early Vegetative Stage," J. Biosci, vol. 35, pp. 4962, 2010.

[5] and G. C. S. Sairam, R.K., D. Kumutha, K. Ezhilmathi, P.S. Deshmukh, "Phisiology and biochemistry of waterlogging tolerance in plants," Biol. Plant, vol. 52, pp. 401-412, 2008.

[6] J. T. Ritche, "Climate and soil water, In Moving up the yield curve. Advace and obstacle," Spec. Publ, vol. 39, pp. 1-2, 1980.

[7] M. M. Hapsari, R.T., Addie, "Peluang Peakitan dan Pengembangan Kedelai Toleran Genengan," J. Litbang Pertan., vol. 29, no. 2, 2010.

[8] L. Fachruddin, Budidaya Kacang-Kacangan. Yogyakarta: Kanisius, 2000.

[9] B. P. T. K. dan U. (Balitkabi), Deskripsi Varietas KacangKacangan dan Umbi-Umbian. Pusat Penelitian dan Pengembangan Tanaman Pangan. 2014.

[10] S. Soedjono, "Aplikasi Mutasi Induksi Dan Variasi Somaklonal Dalam Pemuliaan Tanaman," J. Litbang Pertan., vol. 22, no. 2,
2003.

[11] D. Ermavitalinia, I. P. Sari, E. N. Prasetyo, N. Abdulgani, and T. B. Saputro, "Effect of Gamma 60Co Irradiation On The Lipid Content and Fatty Acid Composition of Nannochloropsis sp. Microalgae," in Proceeding of International Biology Conference, 2016.

[12] Y. C. F. Salsinha, "Pengaruh Iradiasi Sinar $\Gamma$ (Gamma) Co-60 Terhadap Pertumbuhan Padi (Oryza Sativa) 'Situ Bagendit' Pada Cekaman Kekeringan,” Pap. J. Fak. Biol., 2015.

[13] T. B. Saputro, F. Finariyah, S. DIanawati, N. F. Sholihah, and D. Ermavitalini, "In vitro selection of local maize (Zea mays) on $\mathrm{NaCl}$ stress and its genetic characterization using RAPD," $J$. Biol. Biol. Educ., vol. 8, no. 3, pp. 344-351, 2016.

[14] and E. D. T. B. Saputro, N. Fadillatus., "Dynamics Expression Of Osr40c1 Gene And Growth Of Maize (Zea Mays) Calluses In Responding To Salt Stress," Biodiversitas, vol. 18, no. 2, pp 801-808, 2017.

[15] N. F. Sholihah and T.B. Saputro, "In vitro selection of maize (Zea mays L.) varietas Talango and Manding to Salinity Stress," J. Sains dan Seni ITS, vol. 4, no. 1, pp. E60-E63, 2016.

[16] ISTA, "OECD Standards, Scemes and Guides Relating to Varietal Certification of Seed Procedings of the International Seed Testing Association," vol. 36, no. 3, pp. 347-567, 1972

[17] L. Sutopo, Teknologi Benih. Jakarta: CV Rajawali, 1988.

[18] S. Sadjad, Dari Benih Kepada Benih. Jakarta: PT. Grasindo, 1993.

[19] and N. J. T. B. Saputro, K. T. Purwani, V. S. Fatimah, E. M. Stevia, "The Tolerance Improvement of Local Soybean in Waterlogging Condition Through the Combination of Irradiation and In Vivo Selection," J. Phys., vol. 1040, pp. 1-7, 2018.

[20] N. Hendriyani, I.S., dan Setiari, "Kandungan Klorofil Dan Pertumbuhan Kacang Panjang (Vignasinensis) Pada Tingkat Penyediaan Air Yang Berbeda," J. Sains Mat, vol. 17, no. 3, p. $150,2009$.

[21] G. Sitompul, S. M., dan Bambang, Analisis Pertumbuhan Tanaman. Yogyakarta: Gadjah Mada University Press, 1995.

[22] dan T. B. S. I. Prabhandaru., "Respon Perkecambahan Benih Padi (Oryza sativa L.) Varietas Lokal SiGadis Hasil Iradiasi Sinar Gamma," J. Sains dan Seni ITS, vol. 6, no. 2, pp. E48-E52, 2017.

[23] M. Zanzibar and D. J. Sudrajat, "Prospek Dan Aplikasi Teknologi Iradiasi Sinar Gamma Untuk Perbaikan Mutu Benih Dan Bibit Tanaman Hutan," Jakarta, 2009.

[24] H. Purnobasuki, "Kadar Benih," 2011. [Online]. Available http://skp.unair.ac.id/repository/GuruIndonesia/KadarBenih_HeryPurnobasuki_236.pdf.

[25] D. J. dan M. Z. Sudrajat, "Prospek Teknologi Radiasi Sinar Gamma Dalam Peningkatan Mutu Benih Tanaman Hutan," Info Benih, vol. 13, no. 1, pp. 158-163, 2009.

[26] A. Amjad, M and. Akbar, "Effect of post-irradiation storage on the radiation- induced damage in onion seeds," Asian J. Plant Sci, vol. 2, no. 9, pp. 702-707, 2003

[27] S. S. Aisyah, S.I., H. Aswidinoor, A. Saefuddin, B. Marwoto, "Induksi mutasi pada stek pucuk anyelir (Dianthus caryophyllus Linn.) melalui iradiasi sinar gamma," J. Agron, vol. 37, pp. $62-$ 70, 2009.

[28] I. Dwimahyani, "Pengaruh iradiasi sinar gamma terhadap pertumbuhan dan pembungaan stek pucuk krisan (Chrysantemum morifolium Rahmat.) cv. Pink Fiji," J. Ilm. Apl. Isot. dan Radiasi, vol. 3, pp. 67-79, 2007.

[29] G. K. Srivastava, P., "Gamma rays induced alterations in some morphological and biochemical indices of safflower (Carthamus tinctorius L.)," J. Plant Sci. Res, vol. 27, pp. 113-116, 2011.

[30] and M. N. N. F. A. Minisi, M. E. El-Mahrouk, R. M.E.F, "Effect of Gamma Radiation on Germination, Growth Characteristic and Morphological Variations of Moluccella laevis L," Am. J. Agric Environ.Sci, vol. 13, no. 5, 2013.

[31] A. L. P. Kiong, A. G. Lai, S. Hussein, and A. R. Harun, "Physiological Responses of Orthosiphon stamineus Planlets to Gamma Irradiation," Am. J. Sustain. Agric., 2018.

[32] P. D. Kumar, A. Chatuverdi, M. Sreedhar, M. Aparna, P. VenuBabu, and R.K. Singhal, "Gamma Radiosensitivity Study on Rice (Oryza sativa L.)," Asian J. Plant Sci. Res, vol. 3, no. 1, pp. 54-68, 2013.

[33] S. Basi, L. P. Subedi, G. B. K.C, and N. R. Adhikari, "Cytogenetic Effects of Gamma Rays on Indica Rice Radha-4," J. Agric. Anim. Sci, vol. 27, pp. 25-36, 2006.

[34] and W. J. R. Q. H. Li, S. X. Wang, Y. M. Zhao, J. Xu, T. T. 
Gao, "Irradiation Dose and Effect on Germination and Growth of Desert Shrub Nitraria tangutorum Borb. with Two Gamma Irradiation Modes," Pak. J. Bot, vol. 44, no. 2, pp. 661-666, 2012.

[35] C. B. Thapa, "Effects of Acute Exposure of Gamma Rays on Deed Germination and Seedling Growth of Pinus kesiya Gord and P. wallichiana A.B. Jacks," Our Nat., vol. 2, pp. 13-17, 2004.

[36] A. Khawar, I. A. Bhatti, Q. M. Khan, H. N. Bhatti, and M. A. Sheikh, "A Germination Test: an Easy Approach to Know the Irradiation History of Seeds," Pak. J. Agri. Sci, vol. 40, pp. 279$285,2010$.

[37] E. Borzouei, M. Kafi, H. Khazaei, B. Naseriyan, and Majdabadi, "Effects of Gamma radiation on germination and physiological aspects of wheat (Triticum aestivum L.) seedlings," Pak. J. Bot, vol. 42, no. 4, pp. 2281-2290, 2010.

[38] T. B. Nurrachmamila, P. L., Saputo, "Analisis Daya Perkecambahan Padi (Oryza sativa L.) Varietas Bahbutong Hasil Iradiasi," J. Sain dan Seni ITS, vol. 6, no. 2, pp. 2337-3520, 2017.

[39] Shukla et al., "Effect of Gamma Irradiation on Cytokines Released by Planlets During Storage," J. Radiat. Res. Appl. Sci., vol. 9 , pp. $15-19,2016$

[40] M. M. dan A. K. Adie, "Biologi tanaman kedelai," in Dalam Kedelai: teknik produksi dan pengembangannya, Bogor, 2007.

[41] M. I. Surya and H. Soeranto, "Pengaruh Iradiasi Gamma terhadap Pertumbuhan Sorgum Manis (Sorghum bicolor L.)," in Risalah Seminar Ilmiah Aplikasi Isotop dan Radiasi, 2006.

[42] S. Utami, "Uji Viabilitas dan Vigoritas Benih Padi Lokal Ramos Adaptif Deli Serdang dengan Berbagai Tingkat Dosis Irradiasi Sinar Gamma di Persemaian," Agrium, vol. 18, no. 2, pp. 158161, 2013.

[43] M. K. Lesilolo and dan E. A. M. J. Riry, "Pengujian Viabilitas dan Vigor Benih Beberapa Jenis Tanaman yang Beredar di Pasaran Kota Ambon," Agrogolia, vol. 2, no. 1, pp. 1-9, 2013.

[44] Syafruddin and T. Miranda, "Vigor Benih Beberapa Varietas Jagung pada Media Tanam Tercemar Hidrokarbon," J. Floratek, vol. 10, pp. 18-25, 2015

[45] dan T. B. S. V. S. Fatimah, "Respon Karakter Fisiologis Kedelai (Glycine max L.) Verietas Grobogan terhadap Cekaman Genangan," J. Sains dan Seni ITS, vol. 5, no. 2, pp. E71-E77, 2016.

[46] dan T. B. S. E. A. Rohmah, "Analisis Pertumbuhan Tanaman Kedelai (Glycine max L.) Varietas Grobogan Pada Kondisi Cekaman Genangan," J. Sains dan Seni ITS, vol. 5, no. 2, pp.
E29-E33, 2016

[47] M. B. Jackson, "The Impact of Flooding Stress On Plants. And Crops," Uiversity of Bristol, 2003.

[48] J. Kawano, N., Ito, O. \& Sakagami, "Morphological and physiological responses of rice seedlings to complete submergence (flash flooding)," Ann. Bot., pp. 161-169, 2009.

[49] V. N. Y. M. H.I Ramesh., V. Siram., "Antioxidant and Medcinal Properties Of Mulberry (Morus sp.)," World J. Pharm. Res., vol. 3, no. 6, pp. 320-343, 2014.

[50] and A. B. Ferreira, J. L., C. H. M. Coelho, P. C. Magalhaes, E. E. G. e Gama, "Genetic variability and morphological modification in flooding tolerance in maize, variety BRS-4154," Crop Breed. Appl. Biotechnol., vol. 7, pp. 314-320, 2007.

[51] T. . Roger, P.A., Zimmerman, W.J. \& Lumpkin, Microbiological Management of Wetland Rice Fields. Soil Microbial Ecology. New York, 1992.

[52] Z. \& V. D. S. W.M., Vriezen Zhou, "D. Regulation of Submergence -induced Enhanced Shoot Elongation in Oryza sativa L. Annals of Botany,” vol. 91, pp. 263-270, 2003.

[53] J. and T. D. C. M. B., "Response and Adaptation by Plants to Flooding Stress," Ann. Bot., vol. 96, no. 4, pp. 501-505, 2005.

[54] I. K. Sato, T., Harada T, "Stimulation of glycolysis in anaerobic elongation of pondweed (Potamogeton distinctus) turion," J. Exp. Bot, vol. 53, pp. $1847-56,2002$.

[55] T. B. S. K.Nisak., "Respon Perkecambahan Tembakau (Nicotiana tabacum) Varietas Jepon Mawar Hasil Iradiasi Sinar Gamma," J. Sains dan Seni ITS, vol. 6, no. 2, 2017.

[56] E. N. P. and T. B. S. D. Ermavitalini, N. Yuliansari, "Efect of Gamma 60Co Irradiation on The Growth, Lipid Content and Fatty Acid Composition of Botryococcus sp. Microalgae," Biosaintifika, vol. 9, no. 1, pp. 58-65, 2017.

[57] K. T. Sena GAR, "Physiological and growth responses to flooding of seedlings of Hevea brasiliensis," Biotropica, vol. 20, pp. 286-296, 1988.

[58] and N. H. Hopkins, W. G., Introducing to Plant Physiology. USA: John Wiley \& Sons, 2009.

[59] and D. J. C. Burrows, W.J., "Effects of flooding on the root systems of sunflower plants of the cytokinin content in the xylem," sap. Physiol. Plant, vol. 22, pp. 1105-1112, 1969.

[60] J. . Short, K.C., dan Torrey, "Cytokinins in seedlings roots of pea," Plant Physiol., vol. 49, pp. 155-160, 1972.

[61] dan P. Van Toai, T.T., Saglio, P., Ricard, B., "A. Developmental regulation of anoxic stress tolerance in maize," Plant, Cell Environ., vol. 18, pp. 937-942, 1995. 